It is possible that doses of the magnitude mentioned may formerly have been delivered to the skin in some instances, but in contemporary practice (according to information given in a recent joint report of the International Committees on Radiological Protection and on Radiological Units and Measurement) gonad doses in even the most severe fluoroscopic examina. tions are likely to be at least an order of magnitude lower. This one slip apart, the book answers its purpose excellently and can be recommended to all who wish to have a readable and reliable statement of the present stage in the development of the study of human diversity.

C. E. FORD

\section{PHYSICAL AND CHEMICAL EXPLORATION OF THE CELL}

General Cytochemical Methods, Vol. I Edited by Prof. J. F. Danielli. Pp. $x i+471$. (New York: Academic Press, Inc., 1958.) 12.80 dollars.

T HE extraordinary growth in the number of 'annual reviews' or 'recent advances' series poses serious problems for contributors and editors. It is often very valuable for a research worker to review his own field, but once he has become established he may find himself the victim of an insidious process. It is flattering to be invited to contribute reviews and chapters and to take part in symposia; but there is a danger that many active minds are being diverted from research to writing. In some fields the number of reviews almost approaches the number of original papers. The relentless growth of such 'series' is partly to blame. Probably at no other time in the history of science have such a large proportion of reviews been written, and editors must be responsible for the careful selection of subjects and authors so as to avoid overlapping and repetition. The literature on cytological methods is already covered by reviews such as "Progress in Biophysies", "Advances in Medical Physics", and "International Reviews of Cytology," and collaborative works such as "Analytical Cytology", edited by Mellors, and "Physical Techniques in Biological Research", edited by Oster and Pollister.

It is a serious criticism of this new book that five of the nine subjects have already been dealt with (in some cases several times, and even by the same authors) in at least one of the publications mentioned above. Indeed the weight of cellular structures by $X$-rays (Engstrom and Lindstrom) and ultra-violet microspectrophotometry (Walker) have been the subjects of so many reviews that there is little new to offer. Both articles could have been held over for a year or two. The topics of Feulgen microspectrophotometry (Leuchtenberger), autoradiography (Pelc) and fluorescent antibody methods (Coons) have also been extensively reviewed elsewhere. It must be admitted that all these articles are well written and valuable in themselves, but it is rapidly becoming impossible for anyone to keep up with even the review literature.

The remaining four articles cover less familiar ground. Davies gives the fullest account (100 pages) of interference microscopy yet published. This is an admirable article and one wishes that every potential buyer of an interference microscope could be made to produce evidence that he has read and digested its contents. The exhaustive article (nearly 60 pages) by
Bennett and Watts on the demonstration of sulphydryl groups by mercaptide coupling is perhaps less fortunate. One may admire the extraordinary thoroughness of the authors but it is surprising that the second longest article in the book was devoted to a method with (at present) such limited application. By contrast, the article by Holt on indigogenie staining methods for esterases is terse and severely practical. Finally, Danielli himself contributes a short article on the calcium phosphate precipitation method for alkaline phosphatase.

Having approached this book with a critical attitude, one wonders why, despite its imperfections, the general effect is a feeling of satisfaction. The answer is that not only is each of its articles authoritative and informative, but also the work as a whole preserves an integrity that is lacking in some other review journals. The articles are linked by a common theme and purpose and anyone concerned with cytochemistry can be certain that the majority of them will be of interest and value to him. Once this series is firmly established, it is to be hoped that reviews in this field will cease to be dispersed over a wide range of periodicals, thus making the task of the cytologist easier. Even though Prof. Danielli may not have got off to a perfect start, one feels that he is likely to make a very strong finish. R. BARER

\section{PALAOPEDOLOGY}

\section{Soils for the Archæologist}

By Dr. I. W. Cornwall. Pp. 230. (London: Phoenix House, Ltd., 1958.) 50s. net.

$\mathrm{M}^{\mathrm{A}}$ ANY pedologists, like the reviewer, have no doubt been consulted from time to time by archæologists about problems that have arisen in the course of their excavations. That adequate help has not always been fortheoming is in the main due to lack of understanding between the two disciplines, and it is Dr. I. W. Cornwall's aim to reduce this to a minimum. The book is primarily directed at his archæological colleagues, but pedologists could read with advantage Part $I$ of the book and the last chapter, both of which are devoted to a discussion of archæological deposits, but also containing useful information on loess, cave earths and peat. The core of the book is an account of soil types and some methods for their examination, and it is here that the pedologist will find most to argue about. The systematic discussion of the soils is based on Kubiena's "The Soils of Europe", with little modification. While from the morphological point of view this is, in the main, satisfactory, the theories of the underlying processes contain much that is pure guesswork and very debatable. Although Kubiena's techniques are now widely used, his elassification is not generally accepted and it would have been helpful to have mentioned soil groups recognized by other workers, even though an accepted synonymy is not yet established. This would show that what is commonly called a podzol or podzolic soil in the U.S.S.R. need by no means correspond to Kubiena's definition. although it might fit one of his other groups. In this connexion a set of photomicrographs of the types of fabric should have been provided.

There is much use of the theory of peptization of iron oxide by silica for which there is no good evidence, although silica sol will peptize clays. In the British Isles (cf. p. 98), as elsewhere in the 